\title{
Does nitrate fertilization induce nox emission from scots pine (p. sylvestris) shoots?
}

\author{
J. Joensuu • M. Raivonen • A.-J. Kieloaho • \\ N. Altimir • P. Kolari • T. Sarjala • J. Bäck
}

Received: 15 April 2014 / Accepted: 7 November 2014 / Published online: 19 November 2014

(C) The Author(s) 2014. This article is published with open access at Springerlink.com

\begin{abstract}
Aims The possibility of NOx (NO + NO2) emissions from plants and the underlying mechanisms are still under discussion. Excess NO created possibly as a result of nitrite accumulation in plant leaves has been suggested to result in emissions. Such emission has been observed in laboratory conditions due to nitrate fertilization. In this study, we tested whether nitrate fertilization of Scots pine seedlings growing outdoors leads to accumulation of NO3- or NO2- in the needles and subsequent NOx emission.

Methods The experiment was done at the SMEAR II station in Southern Finland. The seedlings received nitrate or ammonium fertilizer or neither. Shoot NOx emissions were measured with dynamic chambers. Total dissolved nitrogen, inorganic nitrogen, NO3-, NO2- and $\mathrm{NH} 4+$ concentrations in the soil and needles were determined.
\end{abstract}

Responsible Editor: Klaus Butterbach-Bahl.

J. Joensuu $(\bowtie) \cdot$ M. Raivonen $\cdot$ N. Altimir $\cdot$ P. Kolari $\cdot$

J. Bäck

Department of Forest Sciences, University of Helsinki,

PO Box 27, 00014 Helsinki, Finland

e-mail: johanna.joensuu@helsinki.fi

M. Raivonen · A.-J. Kieloaho · P. Kolari

Division of Atmospheric Sciences, Department of Physics,

University of Helsinki,

PO Box 48, 00014 Helsinki, Finland

T. Sarjala

The Finnish Forest Research Institute,

Kaironiementie 15, 39700 Parkano, Finland
Results NOx fluxes from the shoots were, on average, deposition. There was no indication of fertilizationinduced NO or NOx emissions. The highest NO fluxes were observed at night and were humidity-related. Conclusions It seems unlikely that additional nitrate in the soil could cause significant NOx emission from boreal Scots pine forests in field conditions, possibly because of soil chemistry.

Keywords Nitrogen oxides - Shoot emissions . Chamber measurements - Nitrogen fertilization

\section{Introduction}

As reactive trace gases in the atmosphere, nitrogen oxides (NOx, here nitric oxide $\mathrm{NO}+$ nitrogen dioxide NO2) have an important role in atmospheric chemistry. Both are taken up by plants through plant stomata, but the possibility of emissions at ambient concentrations below a certain level (known as compensation point) is still under discussion. At high ambient NOx concentrations the observed leaf-level NOx fluxes are always deposition, but when the ambient NOx concentration is low, emission has sometimes been observed (e.g. Teklemariam and Sparks 2006; Hereid and Monson 2001; Thoene et al. 1996), other times not (e.g. Breuninger et al. 2013; Gut et al. 2002; Rondón and Granat 1994; Johansson 1987). Suggested mechanisms underlying the possible emissions include biological and/or physiological reactions (Eller and Sparks 2006; Ramge et al. 1993; Teklemariam and Sparks 2006; 
Wildt et al. 1997) and photochemical surface reactions (Raivonen et al. 2006), but the answers are far from conclusive. It seems also possible that the compensation point (the ambient concentration of NO below which emissions are greater than deposition, resulting in net emission) varies depending on the species (Thoene et al. 1996) and/or conditions like solar radiation and stomatal closure (Raivonen et al. 2009).

NO fluxes between plants and the atmosphere are small compared to NO2 (Rondón et al. 1993; Hereid and Monson 2001), but for plants NO carries more significance. In plants, NO is involved in the regulation of physiological processes such as stomatal closure, germination and defence responses (see Baudoin 2011 for a review). For these purposes, production of NO from nitrite $\left(\mathrm{NO}_{2}{ }^{-}\right)$is catalyzed by a nitrate reductase enzyme (NR); another proposed pathway is production from arginine by a nitric oxide synthase (NOS) (discussed in Fröhlich and Durner 2011 and Gupta et al. 2011). Excess NO created in the NR-nitrite process could then result in NO emission. NO and $\mathrm{NO} 2$ emissions have been observed from plants treated with a herbicide that blocks nitrite reduction (Klepper 1979) as well as from plants lacking the enzyme nitrite reductase (NiR) (Morot-Gaudry-Talarmain et al. 2002), thought to result from reactions of accumulated nitrite and plant metabolites.

Nitrogen present in soil as ammonium (NH4+) or nitrate (NO3-) is easily available to plants. In addition to inorganic nitrogen, plants can uptake amino acids (e.g. Kielland et al. 2007). For use in synthesis of e.g. amino acids, nitrate is first reduced to ammonium in a reaction catalyzed by NR. Depending on the species, this happens either in the roots or in the leaves (Andrews 1986; Lambers et al. 2008). In boreal forest soils inorganic nitrogen species are usually scarce, and plants readily take up all available inorganic nitrogen (Korhonen et al. 2013). Ammonium is generally present in higher concentrations than nitrate in the soil, but nitrogen deposition from the atmosphere creates a man-made addition of both nitrate and ammonium this "fertilization" amounts in Central Finland annually to approximately $7.4 \mathrm{~kg} \mathrm{~N}^{-1}$ (Korhonen et al. 2013). Nitrogen deposition may lower the natural ratio of ammonium and nitrate ions in forest soil (Tang et al. 2012).

Pine trees preferably reduce nitrate already in their roots (Pietiläinen and Lähdesmäki 1988), and nitrogen transportation within the tree therefore mostly happens in other chemical forms. In Scots pine (Pinus sylvestris
L.) NR activity in the needles has been found to be higher in the spring and early autumn (Lähdesmäki and Pietiläinen 1989), when soil temperature is low. This indicates translocation of nitrate from the roots into the needles. Increased needle NR activity has been observed also when pine seedlings have received abundant nitrate fertilization (Sarjala 1991; Pietiläinen and Lähdesmäki 1988). This suggests limited nitrate reduction capacity in the roots and holds evidently for all plant species (Andrews 1986; Andrews et al. 2013). Nitrite accumulating in the needles could then serve as a secondary substrate for NR, leading to NO production and possibly emission from the needles.

Such emission has been observed in laboratory conditions: Wildt et al. (1997) and Rockel et al. (2002) observed clear NO emission from different species of plants, including a coniferous tree (Norway spruce (Picea abies (L.) Karsten)), when given nitrogen as nitrate only, but not when fertilized with an ammonium fertilizer. Teklemariam and Sparks (2006) report leaf $\mathrm{NO}$ emissions from plants grown in an urban atmosphere. A recent study reports potential to emit NO for a range of plant species, including conifers, after simulated nitrogen deposition (Chen et al. 2012). If a similar phenomenon exists in nature, it could affect plantatmosphere interactions in a significant way. Forests growing on nitrate-rich soils could then have higher emissions or a higher compensation point.

The aim of our study was to test whether nitrate fertilization of Scots pine plants leads to accumulation of NO3- or NO2- in the needles and subsequent NOx emission from the shoot, as could be expected based on the literature above. To test this, we fertilized Scots pine seedlings with a nitrate fertilizer, an ammonium fertilizer or neither and measured their shoot NOx emissions.

\section{Materials and methods}

This experiment was conducted in May-July 2012 at the SMEAR II station in Hyytiälä, Southern Finland. For more details on the station and the set-up see Hari and Kulmala (2005) and Raivonen et al. (2003). The plant material consisted of 15 grafted Scots pine seedlings, grown for 5 years in an outdoor plant nursery field. The median height of the seedlings was $141 \mathrm{~cm}$, and the median diameter at the base was $2.4 \mathrm{~cm}$. In late May they were transplanted into 101 plastic pots and kept outdoors in full light. Water was supplied by natural 
rain, which there was plenty of (in June-July 2012 a total of $219 \mathrm{~mm}$, with 33 days of more than $1 \mathrm{~mm}$ of precipitation).

The seedlings were placed atop a $20 \mathrm{~m}$ scaffolding tower 2 weeks before the start of the flux measurements to allow them to recover from transportation stress and acclimate to the environment. The location was chosen to allow fully sunlit conditions within reach of the measurement system originally designed for measuring tall trees (Hari and Kulmala 2005).

In July sun rises at $4 \mathrm{AM}$ and sets before $11 \mathrm{PM}$. In addition, twilight lasts for more than $1.5 \mathrm{~h}$, which results in only a few more or less dark hours per day. In this experiment, "nighttime" refers to the time period 7 PM5 AM.

\section{Experimental design}

The seedlings were randomly assigned to the three fertilization treatments, five to each treatment. The measurement chambers were rotated between treatments.

The gas exchange measurements were done 11-25 June 2012. We had four gas exchange measurement chambers side by side. To prevent varying weather conditions from creating a difference between the treatments, one seedling was measured from each treatment in randomized order and combination at the same time. The fourth measurement chamber was kept empty for blank correction and measured immediately before each round of measurements from the shoot chambers. Each shoot was measured three times per hour for $23 \mathrm{~h}$ (from 7 to 6 p.m.). After all seedlings were measured once, the chambers were cleaned. This cycle was repeated three times, yielding a total of three measurement days per tree. The three chambers were rotated between treatments for each of the three measurement rounds.

The $\mathrm{NO}_{\mathrm{x}}$ fluxes of an empty chamber can vary between individual chambers (Raivonen et al. 2003). For comparison, the four chambers used in this study were measured empty for 2 days at the end of the experiment.

To assess the success of the fertilization treatments we compared nutrient levels of the soil before and after the treatment and needle nutrient levels between the treatments before and after the experiment. The differences in the nutrient levels were tested with one-way ANOVA. The effect on shoot NOx fluxes was assessed by comparing the fluxes between the three different treatments. The goodness of fit of the mass balance was evaluated by calculating the residual sum of squares (RSS) for each fitting (each closure).

\section{Fertilization}

The seedlings received three different fertilization treatments: fertilization with ammonium sulphate (NH4)2SO4, fertilization with potassium nitrate, $\mathrm{KNO} 3$ or no nitrogen fertilization. To compensate for the fertilizing effect of potassium in the nitrate fertilizer, the ammonium and control treatments received the same amount of potassium as potassium sulphate K2SO4. Accumulated dirt and chemical compounds, probably nitrogenous, may affect the observed NOx fluxes via chemical reactions on needle surfaces (Raivonen et al. 2006). To minimize this effect, we applied the nutrient solution as irrigation instead of spraying. The fertilization was given in three doses along 8 weeks, the first one in early June and the last one on the day before the last round of measurements for each seedling. For both nitrogen treatments, the total fertilizer dose was equivalent to $1.0 \mathrm{~g} \mathrm{~N} /$ seedling or approximately $20 \mathrm{~g} \mathrm{~N} \mathrm{~m}^{-2}$, which is approximately 60 times the annual nitrogen deposition in the area (Lindroos et al. 2002).

\section{Gas-exchange measurements}

We measured the shoot-level gas fluxes ( $\mathrm{NO}, \mathrm{NOx}, \mathrm{O} 3$, $\mathrm{CO} 2$ and $\mathrm{H} 2 \mathrm{O}$ ) with the dynamic field gas-exchange system described in Altimir et al. (2002) and Raivonen et al. (2003), using four box-shaped chambers with a volume of $1 \mathrm{dm}^{3}$. The chambers were made of plexiglass coated on the inside with FEP film with silicone adhesive, with an UV-transparent quartz glass roof. Each chamber enclosed a single shoot; the biomass of the shoot was on average $4.4 \mathrm{~g}$ of fresh weight (2.1$7.6 \mathrm{~g})$.

$\mathrm{NO}$ and $\mathrm{NO} 2$ concentrations were each measured with a chemiluminescence analyzer (TEI 42CTL, Thermo Environmental Instruments, USA). The instrument used for NO2 measurements was equipped with a photolytic converter (BLC, Droplet Measurement Technologies). $\mathrm{CO} 2$ and $\mathrm{H} 2 \mathrm{O}$ concentrations were measured with a URAS 4 analyzer (Hartmann and Braun, Germany). We also measured temperature inside the chamber and photosynthetically active radiation (PAR) on top of the chamber. UV radiation measurements, ambient NOx and $\mathrm{O} 3$ measurements and additional meteorological measurements (ambient temperature, 
precipitation) were available from a nearby measurement mast at $16.8 \mathrm{~m}$ from the ground (horizontal distance from the experiment was $50 \mathrm{~m}$ ).

Most of the time the measurement chamber was open, allowing ambient air to enter and keeping conditions inside the chamber close to ambient (not including precipitation). At the start of a measurement, the chamber closed. During the 1-min closure, the gas concentrations at the chamber outlet were measured at 5-s intervals. The sample flow $(4.8 \mathrm{l} / \mathrm{min})$ was replaced by ambient air flowing into the chamber at an equal rate. The incoming ambient air is assumed to have the concentration measured in the open chamber just before the measurement. When not in measurement, the chambers were well-ventilated, keeping conditions inside the chamber close to ambient (not including precipitation).

The gas analyzers measured the concentration of each gas in the chamber at 5-second intervals. From the concentration development in the chamber, we estimated the gas flux from the shoot (and/or chamber) using a mass balance equation (Altimir et al. 2002; Raivonen et al. 2003). The full $60 \mathrm{~s}$ dataset for each closure was used for calculating the fluxes. The flux observed in the empty chamber was subtracted from the fluxes in each shoot chamber to obtain the flux from the shoot. After the measurement, the shoot was cut from the tree, photographed and the needles were weighed. All-sided needle area was estimated from the photograph using the ImageJ software (Schneider et al. 2012). We then dried the needles at $70{ }^{\circ} \mathrm{C}$ for $48 \mathrm{~h}$ and weighed again.

The detection limit of the NO analyzer is $0.1 \mathrm{ppb}$, accuracy $0.3 \mathrm{ppb}$ and precision $0.05 \mathrm{ppb}$ (Raivonen et al. 2006). The identical NO2 is affected by the NO2 conversion efficiency (0.48), resulting in $0.3 \mathrm{ppb}$ detection limit and $0.15 \mathrm{ppb}$ precision. Because of the requirements of the fast chamber measurement system, the absolute concentration values are not always accurate, which is why we generally use the mast measurements to describe ambient concentrations. The ambient NO concentrations measured from the chamber system (while the chamber is open) have been constantly slightly higher (by $0.2-0.4 \mathrm{ppb}$ ) than those measured from the mast (Raivonen et al. 2014). Since the flux measurement is based on concentration differences rather than absolute concentrations, this possible inaccuracy does not influence the results. The properties of our measurement system are described in detail in Raivonen et al. 2014.
Chemical analyses

In order to determine the fertilization effect, we sampled the seedlings for needles and soil before the treatments and in the end of the experiment. Before the experiment, only second-year needles were available, since budburst had not yet occurred. From soil samples, we determined $\mathrm{pH}_{\mathrm{H} 2 \mathrm{O}}$ and gravimetric soil water content and extracted the rest of the sample with $1 \mathrm{M}$ potassium chloride $(\mathrm{KCl})$ for exchangeable inorganic and organic nitrogen. To achieve a soil-solution ratio of 1:5, approximately $2 \mathrm{~g}$ of fresh soil was weighed in $50 \mathrm{ml}$ centrifuge tubes, in which $20 \mathrm{ml}$ of $1 \mathrm{M} \mathrm{KCl}$ was added. The mixture was shaken with reciprocal shaker (100 rpm) for $80 \mathrm{~min}$ at room temperature to ensure effective extraction. Raw extracts were then filtered through $0.45 \mu \mathrm{m}$ cellulose acetate filters (Pall Life Science, US, Michigan, Ann Arbor) and frozen in $-20{ }^{\circ} \mathrm{C}$ until analysis.

The needle samples were frozen in liquid nitrogen immediately after sampling, ground at $-196^{\circ} \mathrm{C}$ and kept deep-frozen until extraction. The extraction method for needles was a modification of the method introduced by Sarjala (1991). $0.5 \mathrm{~g}$ of ground fresh needle mass was weighed in a $2 \mathrm{ml}$ centrifuge tube, and $1.5 \mathrm{ml}$ of $80 \mathrm{mM}$ phosphate buffer ( $\mathrm{pH} 7.5$ ) with $5 \%$ 2-propanol was added. For effective extraction, the samples were kept under vacuum for $10 \mathrm{~min}$ and then centrifuged (5000 rpm) for $20 \mathrm{~min}$ to separate the extract from the needle mass. The extracts were then filtered through $0.45 \mu \mathrm{m}$ cellulose acetate filters (Whatman $\mathrm{GmbH}$, Germany, Dassal). The needle extractions for nitrate, nitrite and total dissolved nitrogen analysis analysis were stored in $-20^{\circ} \mathrm{C}$ until analysis.

We used colorimetric microplate assay methods introduced by Hood-Nowotny et al. (2008) to determine inorganic nitrogen, nitrate (NO3-), nitrite (NO2-) and ammonium $(\mathrm{NH} 4+)$ concentrations in the soil and needle extracts. The colorimetric assay for $\mathrm{NH} 4+$ was a modified indolphenol method based on the Barthelot reaction (Kandeler and Gerber 1988) and a modified acidic Griess reaction was used for NO2- and NO3-. For the acidic Griess reaction to occur, vanadium chloride (VCl3) was used to reduce NO3- to NO2-. Absorbance values were measured with a microplate reader (Infinite M200, Tecan Group Ltd., Swizerland, Männedorf).

Dissolved organic nitrogen content was calculated by subtracting the sum of inorganic nitrogen species from total dissolved nitrogen. Total dissolved nitrogen was determined by a total organic carbon analyser equipped 
with total nitrogen unit (TOC-Vcph/cpn TNM-1, Shimadzu Corporation, Japan, Kyoto).

\section{Results}

Ambient conditions

The weather was intermittently cloudy with frequent rain showers for the duration of the 3-week measurement campaign (Fig. 1). Daily maximum temperature varied from 14.2 to $20.7^{\circ} \mathrm{C}$ and precipitation from 0 to $13 \mathrm{~mm}$. The average daily maximum temperature in July at the station is $21.7^{\circ} \mathrm{C}$ (Pirinen et al. 2012) and the average number of rain days $(\geq 0.1 \mathrm{~mm})$ is 17 .

Due to technical problems, ambient NOx and O3 measurements from the mast were only available for the first and last days of July, covering only the last 3 days of the experiment. On these days, ambient NOx concentration was $0.1-1 \mathrm{ppb}$, while ambient $\mathrm{O} 3$ concentration was $20-45 \mathrm{ppb}$, both typical of the location and season (Kulmala et al. 2000). Ambient NO concentrations were $0-0.14 \mathrm{ppb}$ with the lowest values at night. Between $7 \mathrm{PM}$ and $5 \mathrm{AM}$ ambient $\mathrm{NO}$ concentration was $0-0.04 \mathrm{ppb}$. The ambient concentration measurements from the open chambers, while not optimized for this use, give no indication of any unusual NOx of $\mathrm{O} 3$ concentrations during the experiment. We also calculated the possible effect of reactions with $\mathrm{O} 3$ in the chamber and sample line on the observed NO fluxes, but the effect was negligible.

\section{Effect of fertilization on tree growth}

The measured current-year shoots varied somewhat in size and stage of needle development, but this variation showed no relationship to the fertilization treatment. This was to be expected, since pine shoot growth is
Fig. 1 UVA radiation, ambient air temperature, precipitation and $\mathrm{RH}$ (at $16.8 \mathrm{~m}$ ) during the measurement campaign (July 11-25, 2012)
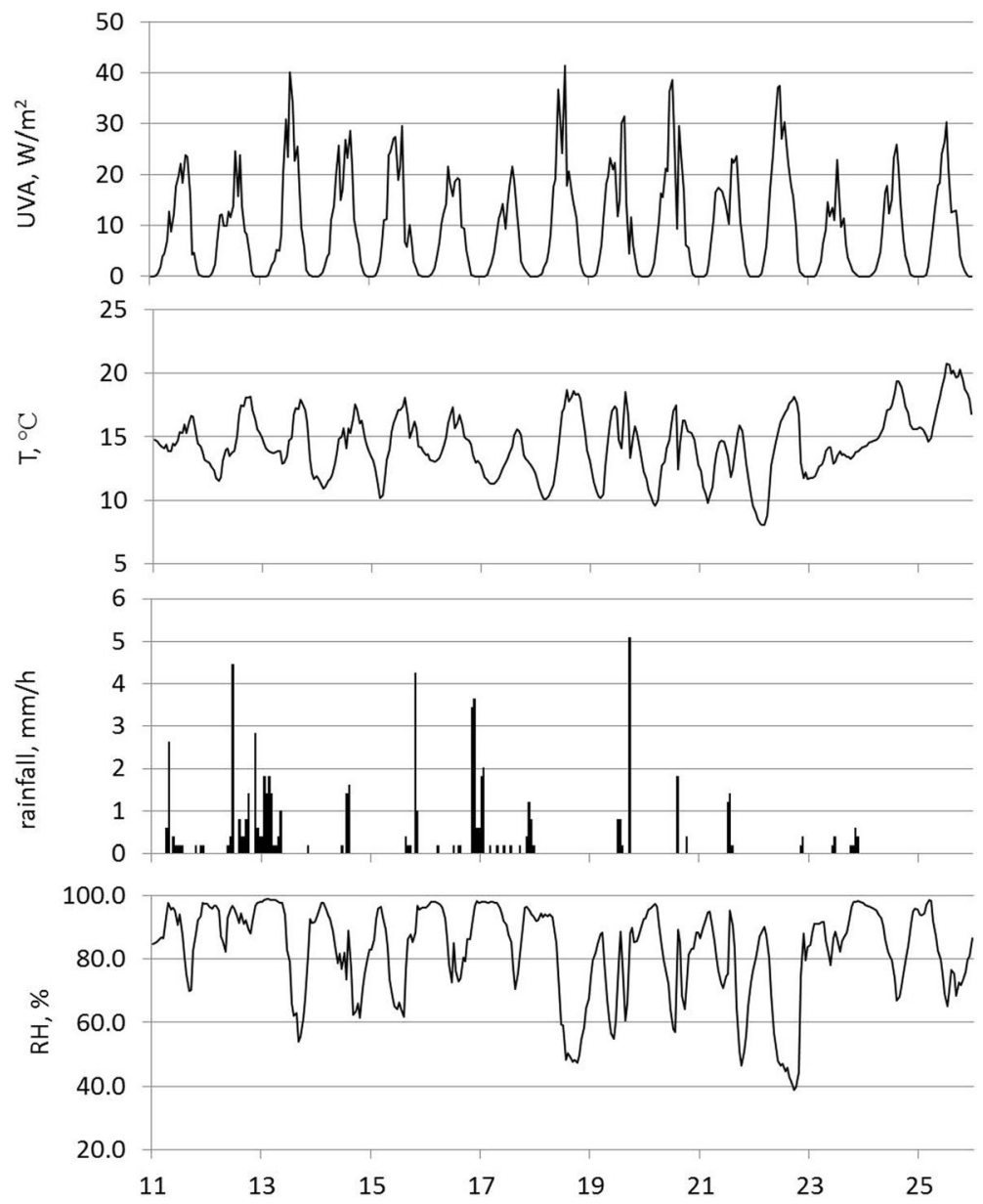
predetermined and depends mostly on the growth conditions of the previous summer. Furthermore, there were no significant differences in the specific dry needle mass (per needle area) or moisture content between the treatments.

Effect of fertilization on the $\mathrm{N}$ concentrations of soil and needles

Soil nutrient content was very similar before the treatments and very different after the experiment between the treatments, as was expected (Table 1). After the experiment, soil $\mathrm{NH} 4+$ content was more than 150 fold in the $\mathrm{NH} 4+$ treatment and over sixfold in the NO3- treatment, compared with the control $(165,7.34$ and $1.08 \mu \mathrm{gN} / \mathrm{gDW}$, respectively), while soil NO3content was over 90-fold in the NO3- treatment and more than 16-fold in the $\mathrm{NH} 4+$ treatment compared with the control $(185,32.7$ and $2.03 \mu \mathrm{gN} / \mathrm{gDW}$, respectively). Soil NO2- content increased in the NH4+ and NO3- treatments, but not as dramatically. These changes were naturally reflected in the values for total inorganic, but also total organic nitrogen content. Soil $\mathrm{pH}$ after the experiment in the NO3-, NH4+ and control treatments was 5.4, 4.7 and 5.2 (respectively).

Needle nitrite, nitrate and DTN (total dissolved nitrogen) contents of second-year needles were very similar in all treatments before the fertilization. The average nitrite concentration was $0.57 \mu \mathrm{g} \mathrm{N} / \mathrm{g}$ of fresh needles, nitrate $5.9 \mu \mathrm{g} \mathrm{N} / \mathrm{g}$ and DTN $247 \mu \mathrm{g} \mathrm{N} / \mathrm{g}$. After the experiment there was some indication of a lower nitrite and nitrate concentration in the first-year needles of the NO3- treatment and lower dissolved total nitrogen in the control treatment compared with the other two, although the variation was quite large. Accordingly, the differences were not statistically significant $(p>0.05)$. The average nitrite concentration was $0.42 \mu \mathrm{g} \mathrm{N} / \mathrm{g}$ of fresh needles, nitrate $5.0 \mu \mathrm{g} \mathrm{N} / \mathrm{g}$ and DTN $178 \mu \mathrm{g} \mathrm{N} / \mathrm{g}$ in the first-year needles after the experiment.

Blank chamber

Chamber measurements of NOx fluxes are often limited by the chamber blank: signal-to-noise ratio is small when the plant-related fluxes are small. Therefore, we analyzed the blank chamber carefully in order to be able to evaluate whether the fluxes we see are plant-related or not. The average NOx flux in the always empty chamber was practically zero $(0.15 \mathrm{pmol} / \mathrm{s})$ (Fig. 2$)$. The values for individual closure ranged from $-6.85 \mathrm{pmol} / \mathrm{s}$ (deposition) to $6.60 \mathrm{pmol} / \mathrm{s}$ (emission); these extreme values are not visible in Fig. 2 with hourly averaging. The average NO flux was $0.41 \mathrm{pmol} / \mathrm{s}$ (range -0.66 to $2.55 \mathrm{pmol} / \mathrm{s}$ ) (Fig. 2). The NOx or NO emissions did not show a clear daily pattern. The NO emissions were strongly humidity-related. For the NOx fluxes there was no such connection.

We observed NOx emission from the chambers that held the shoots even after the experiment, when they were measured empty alongside the blank chamber (Fig. 3). These 2 days were warm and sunny, with daily maximum temperatures reaching $25^{\circ} \mathrm{C}$. Ambient NOx concentration remained at or below $1 \mathrm{ppb}$. The $\mathrm{NOx}$ emissions from the previous shoot chambers assumed a clear diurnal pattern with emissions peaking at midday. NO emission was observed on the latter of the 2 days, without a diurnal pattern (Fig. 3). RH was very high on the second day.

\section{Fluxes in shoot chambers}

The NOx fluxes from all four chambers (including the empty chamber) behaved very similarly during the experiment (Figs. 2 and 5). The average NOx flux in the chambers with a shoot (without correcting for the flux in

Table 1 Nitrogen content of the soil samples ( $\mu \mathrm{gN} / \mathrm{gDW})$ before and after the experiment

\begin{tabular}{llllllllllllllll}
\hline & A & B & A & B & A & B & A & B & A & B & A & B & A & B \\
\hline Treat. & NO2- & & NO3- & & NH4- & & \multicolumn{2}{l}{ Total (inorg.) } & \multicolumn{1}{l}{ DTN } & & Total (org.) & $\%$ org. \\
NH4- & 0.002 & 0.007 & 0.047 & 32.717 & 0.793 & 164.508 & 0.842 & 197.232 & 13.298 & 303.545 & 12.456 & 106.313 & 93.8 & 32.4 \\
NO3- & 0.002 & 0.011 & 0.065 & 184.734 & 0.750 & 7.342 & 0.817 & 192.086 & 14.051 & 438.049 & 13.234 & 245.963 & 94.0 & 54.4 \\
Control & 0.003 & 0.003 & 0.075 & 2.028 & 0.638 & 1.075 & 0.716 & 3.106 & 12.515 & 14.488 & 11.799 & 11.382 & 94.0 & 74.3 \\
\hline
\end{tabular}

$\mathrm{A}=$ before experiment, $\mathrm{B}=$ after experiment 

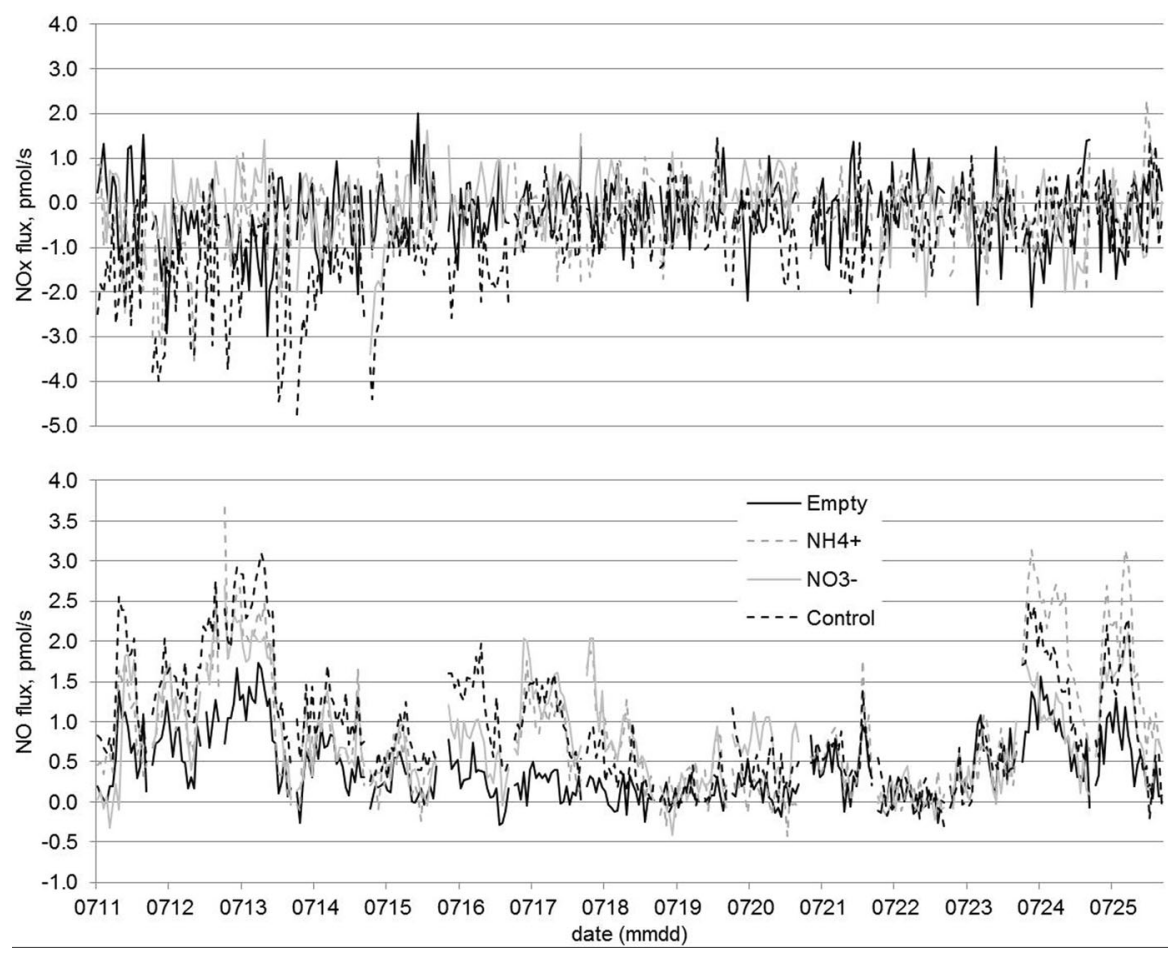

Fig. 2 Time series (hourly averages) of the NOx and NO fluxes in the shoot chambers and the empty chamber during the experiment. Positive sign indicates emission
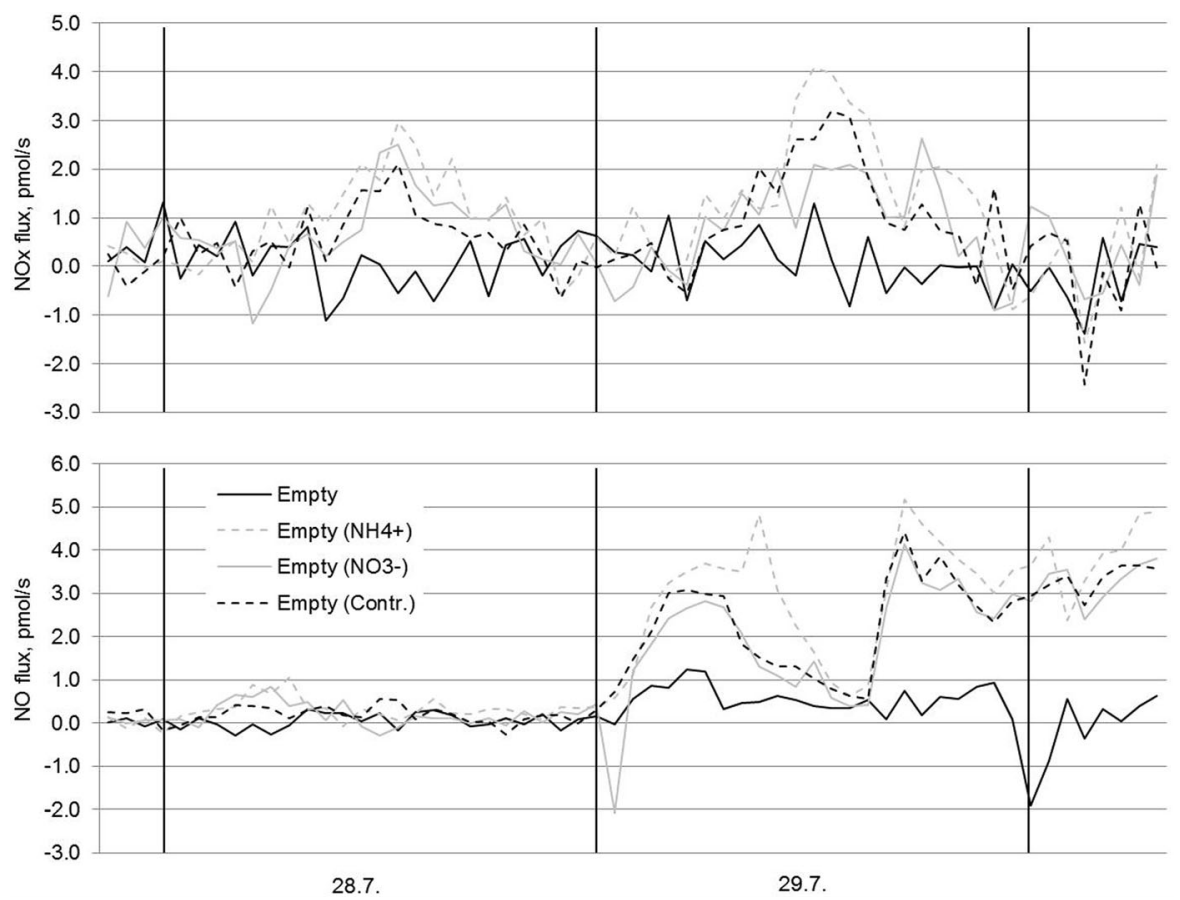

Fig. 3 Hourly average NOx and NO fluxes in empty chambers after the experiment. Positive sign indicates emission 
the empty chamber) in the NH4+, NO3- and control treatments was slightly on the side of deposition $(-0.36 \mathrm{pmol} / \mathrm{s},-0.38 \mathrm{pmol} / \mathrm{s}$ and $-1.01 \mathrm{pmol} / \mathrm{s}$, respectively, with values ranging from -6.19 to $4.24 \mathrm{pmol} / \mathrm{s}$ ). Variation in all the fluxes was large and RSS values were often extremely high, especially for the empty chamber. The shoot chambers showed no daily flux pattern for NOx (Fig. 4). After correcting for the empty chamber, the average NOx flux in the chambers with a shoot in the NH4+, NO3- and control treatments was $-0.050 \mathrm{nmol} / \mathrm{m} 2 / \mathrm{s},-0.036 \mathrm{nmol} / \mathrm{m} 2 / \mathrm{s}$ and $-0.11 \mathrm{nmol} /$ $\mathrm{m} 2 / \mathrm{s}$, respectively, with values ranging from -0.88 to $0.30 \mathrm{nmol} / \mathrm{m} 2 / \mathrm{s}$.

For the NO fluxes, the picture is more diverse (Figs. 2 and 5). Sometimes the fluxes in all chambers were very similar and close to zero (e.g. July 21-23), while at other times there was clear emission from the shoot chambers, but not the empty one (e.g. July 16-17). The average flux in the shoot chambers (without correcting for the empty) in the NH4+, NO3- and control treatments was emission $(0.85 \mathrm{pmol} / \mathrm{s}, 0.79 \mathrm{pmol} / \mathrm{s}$ and $0.91 \mathrm{pmol} / \mathrm{s}$, respectively, with values ranging from $-0.79 \mathrm{pmol} / \mathrm{s}$ to $3.79 \mathrm{pmol} / \mathrm{s}$ ). The shoot chambers showed a daily flux pattern for NO, with highest emissions towards the end of the night (Fig. 4). A similar pattern was observed in all treatments. There was no systematic difference between individual chambers (that were rotated between treatments) or individual trees, neither could we observe a clear difference in the mean fluxes for the different treatments (Fig. 5). After correcting for the empty chamber, the average NO flux in the chambers with a shoot in

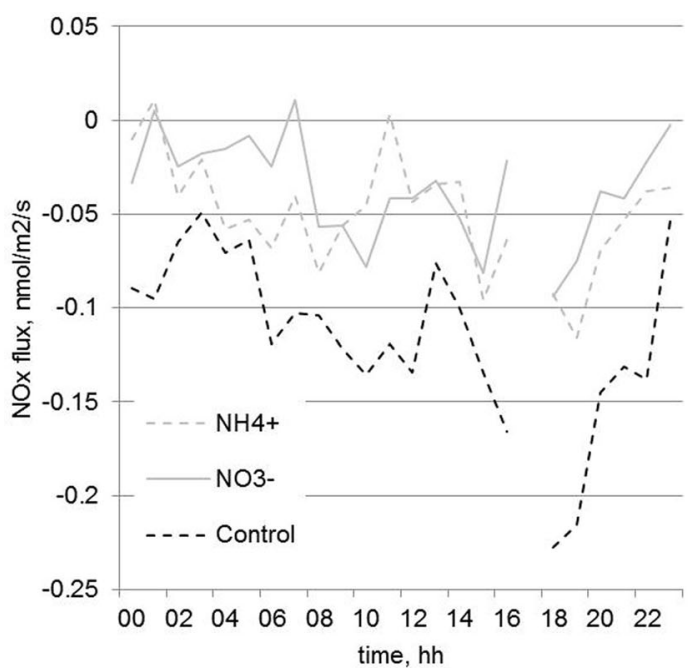

the $\mathrm{NH} 4+, \mathrm{NO} 3-$ and control treatments was $0.051 \mathrm{nmol} / \mathrm{m} 2 / \mathrm{s}, 0.038 \mathrm{nmol} / \mathrm{m} 2 / \mathrm{s}$ and $0.057 \mathrm{nmol} /$ $\mathrm{m} 2 / \mathrm{s}$, respectively, with values ranging from -0.17 to $0.57 \mathrm{nmol} / \mathrm{m} 2 / \mathrm{s}$.

The CO2 flux of the shoots was used as an indicator of plant activity. There was no systematic difference in the $\mathrm{CO} 2$ fluxes between the treatments. We also analyzed the relationship of the observed NOx fluxes with ambient NOx and O3 (measured from the open chamber), UVA radiation and temperature. Ambient NOx showed a weak relationship with the observed flux: at higher ambient NOx there was slightly more uptake. There was no difference between the treatments in this respect. The comparison of UVA, temperature and $\mathrm{CO} 2$ flux to those of NOx and NO fluxes gave no indication of any of these having a marked effect on the NOx or NO flux.

The highest NO fluxes were observed at nighttime (Figs. 2 and 6). On some nights the fluxes from the empty chamber were very similar to those from the chambers with a shoot, but on other nights all chambers with a shoot inside showed a clearly larger flux than the empty chamber. The nighttime NO fluxes were highest on rainy nights (Fig. 6). The NO emissions in the shoot chambers were even more strongly humidity-related than those in the empty chamber (Fig. 7).

\section{Discussion}

As opposed to the results by Wildt et al. (1997), Rockel et al. (2002) and Chen et al. (2012), we observed no

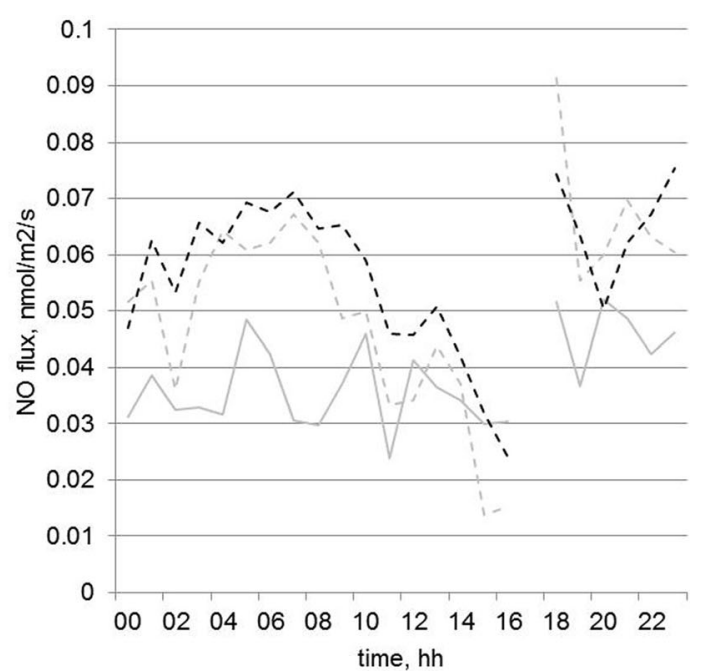

Fig. 4 Average daily patterns on NOx and NO fluxes in in the shoot chambers (after correcting for the flux in the empty chamber) during the experiment. Positive sign indicates emission 

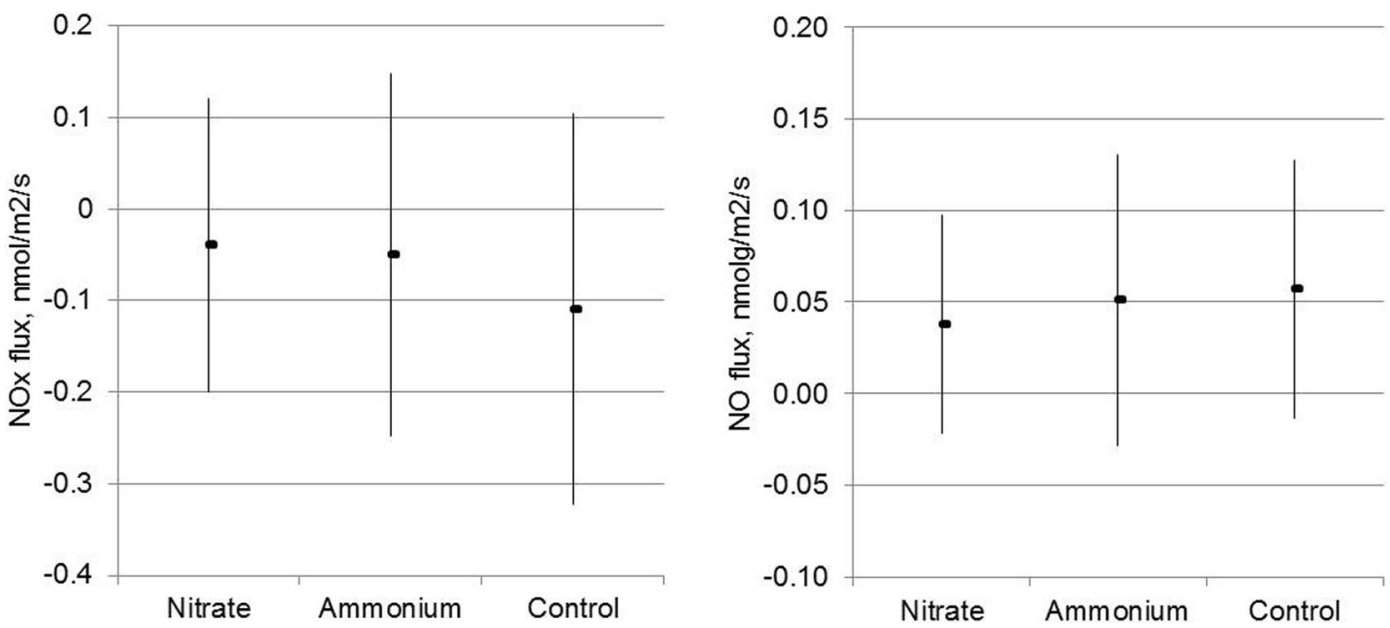

Fig. 5 Shoot-level NOx and NO fluxes in the different fertilization treatments (mean +- SD) after correcting for the flux in the empty chamber. Positive sign indicates emission

indication that nitrate fertilization would induce emissions of NO or NOx from Scots pine shoots. There was NO emission from the chambers with seedlings, but the fertilization treatment did not affect the magnitude of the flux. Our observed shoot NO fluxes $(-0.17-0.57 \mathrm{nmol} /$ $\mathrm{m} 2 / \mathrm{s}$, mean $0.038-0.057 \mathrm{nmol} / \mathrm{m} 2 / \mathrm{s}$ ) are close to the range observed by Wildt et al. (1997). In their laboratory experiment, Wildt et al. (1997) generally observed NO fluxes in the range $0-0.04 \mathrm{nmol} / \mathrm{m} 2 / \mathrm{s}$, with occasional uptake, for sunflowers grown in a hydroponic solution; they report a maximum value of $0.15 \mathrm{nmol} / \mathrm{m} 2 / \mathrm{s}$. The highest emissions were seen during the first hours of the photoperiod, but after adding NO3- to the growth medium, they observed transient nighttime peaks up to $0.5 \mathrm{nmol} / \mathrm{m} 2 / \mathrm{s}$. For a sunflower growing in soil, they report a nighttime maximum emission of $0.3-0.4 \mathrm{nmol} /$ $\mathrm{m} 2 / \mathrm{s}$. For spruce they only report that it was "similar to agricultural plants" regarding $\mathrm{NO}$ emissions. The potential $\mathrm{NO}$ emissions $(0.014 \mathrm{nmol} / \mathrm{m} 2 / \mathrm{s})$ observed from conifers after simulated $\mathrm{N}$ deposition by Chen et al. (2012) are also similar to our mean fluxes. The potential NO emission without simulated $\mathrm{N}$ deposition $(0.003 \mathrm{nmol} / \mathrm{m} 2 / \mathrm{s}$, Chen et al. 2012) is much lower than the mean flux in the control treatment of our study $(0.057 \mathrm{nmol} / \mathrm{m} 2 / \mathrm{s})$. Chen et al. (2012) do not specify if they used one- or all-sided leaf area in their calculations. Also the NO fluxes $(-0.003-0.070 \mathrm{nmol} / \mathrm{m} 2 / \mathrm{s})$ reported by Teklemariam and Sparks (2006) are in the same range.

The NOx fluxes in the shoot chambers were, on average, deposition. The fertilization treatments did not turn the net NOx fluxes into emission. Any NOy emissions (including more oxidized nitrogenous species, like HONO and N2O5, and organic nitrogen species such as peroxyacyl nitrates (PANs), in addition to NOx) from the shoot chambers could be expected to be highest in sunny and warm weather with high UVA radiation (Raivonen et al. 2006), and emissions of a physiological origin would likely correlate with photosynthesis. Neither was observed. On the contrary, the highest NO fluxes were observed at night and were related to humidity. It is worth notice that in the Scandinavian summer, "nighttime" is a much more vaque concept than in a laboratory.

The high variability of the observed NOx fluxes may at least partly be caused by variability in atmospheric conditions. The observed relationship between ambient NOx and the NOx flux is in line with earlier studies setting the compensation point of NOx exchange at 0.33 ppb (see Raivonen et al. 2009 for a review); the variation in the ambient NOx concentration covers many of the reported compensation concentrations. It has to be noted, however, that not all studies have found a compensation point. None of the other variables showed a relationship to the observed NOx fluxes. Since all treatments were measured side by side, any variations in ambient concentrations were experienced by all treatments and should not hinder comparison.

The fertilization of the soil seemed to be successful: the nutrient concentrations were higher in the fertilized pots. The extremely high nutrient concentrations after the experiment reflect the fact that the last fertilizer application was done very close to the end of the experiment; the fertilizer was unevenly distributed in the soil, 
Fig. 6 Night-time shoot-level NOx flux (top) and NO flux (bottom) in the different fertilization treatments (mean $+-\mathrm{SD}$ ) after correcting for the flux in the empty chamber. Left panel: rainy nights (precipitation $>5 \mathrm{~mm}$ ), right panel: dry nights. Positive sign indicates emission
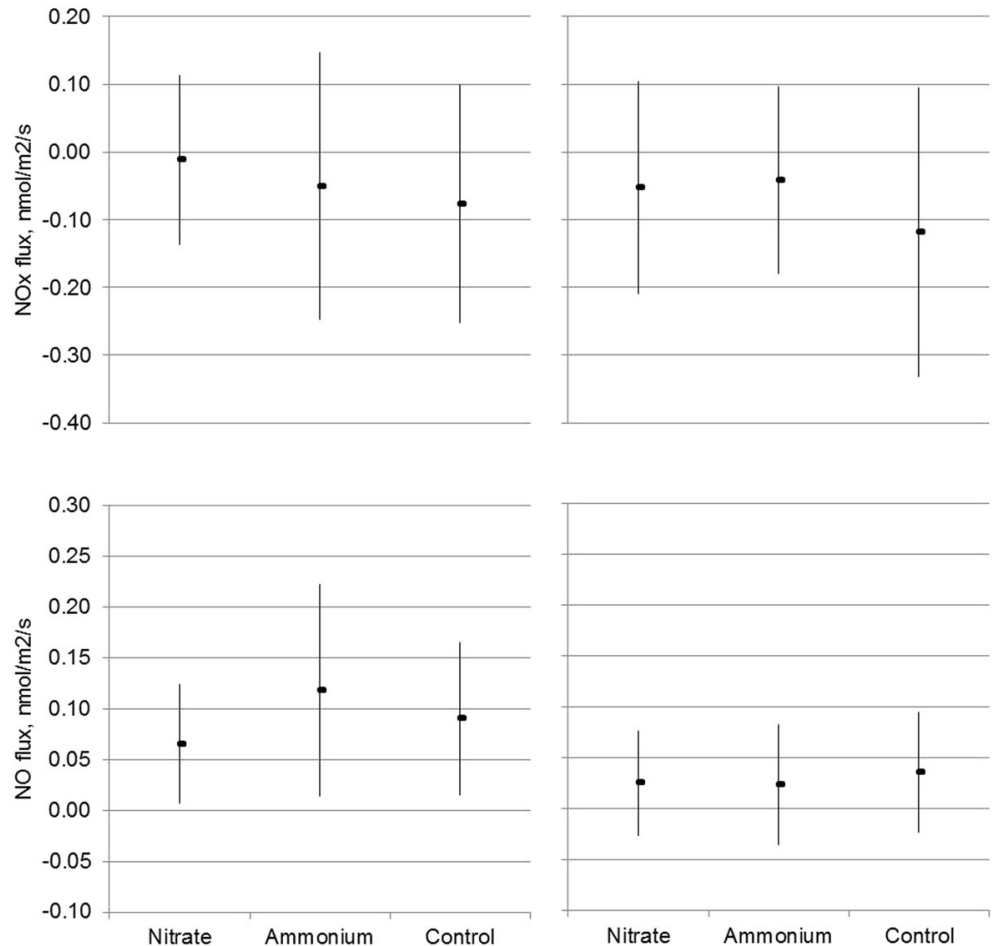

concentrated in the topmost layer where the soil sample was taken. Soil nitrate and nitrite as well as soil organic nitrogen increased in both nitrogen fertilization treatments as a result of soil chemistry. Soil $\mathrm{pH}$ changed because NO3- is a weak base, whereas NH4+ is a weak acid.

Although the soil clearly received high nitrogen inputs, we observed no significant differences in the nutrient concentrations of the needles. The fertilization treatment was started before the onset of needle elongation, so the nutrients were available to the trees at the time of growth. The slightly lower DTN content of the unfertilized first-year needles indicates that the fertilization did reach the needles during the experiment. The slightly lower nitrite and nitrate content in the NO3treatment could be a result of NO3- induced NR activity
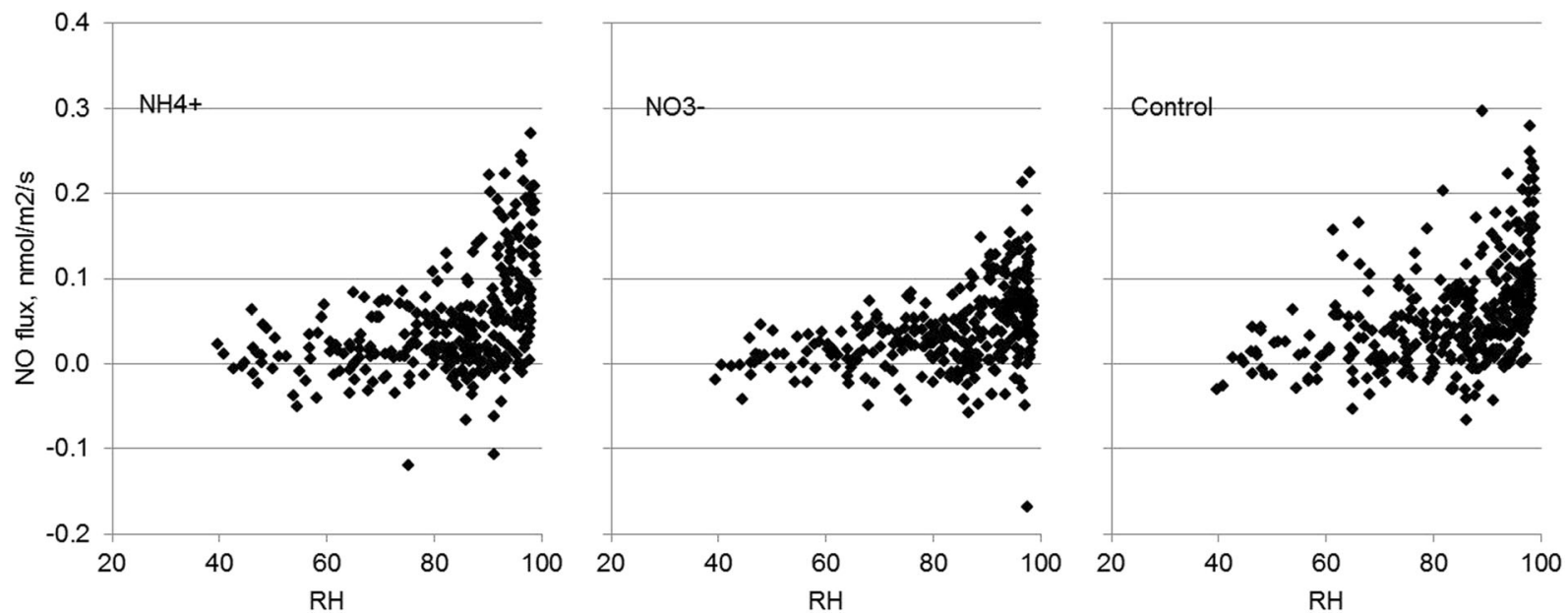

Fig. 7 Relationship of NO flux (hourly average) from the shoot chambers (after correcting for the flux in the empty chamber) to relative humidity. Positive sign indicates emission 
in the treatment compared with the NH4+ and control treatments. Unfortunately, an ammonium analysis was not possible due to technical limitations. In natural conditions, NR activity in Scots pine needles shows a seasonal low during the summer months (Pietiläinen et al. 1991). During our experiment, the abundant fertilization could have induced "unseasonal" NR activity in the needles. Such induction has been observed with NO3- fertilization for pines grown in nutrient solution (Pietiläinen and Lähdesmäki 1988). Most studies concerning needle nutrients report the total $\mathrm{N}$ content of the needles. The method used in this study reports dissolved total nitrogen, preventing direct comparison.

The NOx emissions from the empty shoot chambers after the experiment add uncertainty to the measurements. The emissions originate most likely in nitrogenous compounds accumulating on the chamber surfaces during the experiment. A similar phenomenon has been reported and discussed by Raivonen et al. (2006). This accumulation happened despite the regular cleanings (every 5 days) during the experiment. There was no difference in this respect between the individual shoot chambers. The chambers were rotated between treatments (after every washing); it is also likely that the shoots affected the chambers similarly regardless of the fertilization. Since the maximum NO emissions from an empty shoot chamber after the experiment are similar to the maximum emissions with a shoot, the relative contributions of the shoot and the chamber cannot be distinguished. However, it is unlikely that the chamber effect could have covered shoot emissions on the scale observed by Chen et al. (2012) and Wildt et al. (1997).

Our hypothesis was that fertilization would increase the nitrite concentrations in the needles and the accumulated nitrite would be released as NOx. Since there were no differences in the nitrite concentration of the needles (Table 1), there were no differences in the amount of available substrate for the enzymatic creation of NO, explaining the similar fluxes.

Wildt et al. (1997) and Rockel et al. (2002) performed most of their experiments in laboratory conditions, where the nutrient concentrations in the growth medium could be kept constant. However, Wildt et al. (1997) did observe NO emission also from plants grown in a nutrient solution with both $\mathrm{NH} 4+$ and NO3- and a spruce seedling grown in soil, especially when the soil was wet. Soil wetness seems to play an important role, since also in our experiment the highest $\mathrm{NO}$ emissions were observed on rainy nights. This could be a result of increased nutrient mobility and availability to the roots; High soil NO3- concentrations are known to shift the NO3- assimilation more towards the shoots in some, but not all, agricultural plants (Andrews et al. 2004). Chen et al. (2012) too did their research on soil-grown seedlings, but measured the "potential NO emission" from a cut leaf rather than a shoot attached to a living tree.

Wildt et al. (1997) observed NO emission only from plants that had NO3- in their growth medium and considered NO3- in the soil a prerequisite for $\mathrm{NO}$ emission. In our experiment, the NO emissions seemed unrelated to the amount of NO3- in the soil. In natural conditions, microbes living in the soil, soil moisture and $\mathrm{pH}$ all affect the NH4+/NO3- balance, among other things. Nitrification in fertilized Finnish forest soils is favored by high pH (Paavolainen and Smolander 1998), but it can occur even in acidic soils, especially if the soil is rich in ammonium (De Boer et al. 1990; Martikainen et al. 1993; Persson and Wirén 1995; Paavolainen and Smolander 1998). Denitrification, on the other hand, is favored by high soil moisture, high nitrate concentration, high $\mathrm{pH}$ and high temperature (Federer and Klemedtsson 1988; Willison and Anderson 1991; Henrich and Haselwandter 1991, 1997). Changes in nutrient input, in turn, alter the microbial flora in the soil (Frey et al. 2004; Wallenstein et al. 2006). The soil nutrient status experienced by the tree may therefore not be as clearly dominated by either NH4+ or NO3- as might be expected from the treatments alone. Also, boreal forest soils tend to have low concentrations of inorganic nitrogen, especially in nitrate (Korhonen et al. 2013). An experiment like ours could then be expected to cause a dramatic increase in either NH4+ or NO3-. If, however, these ions are already present in significant amounts or are interconverted through soil chemistry, a true either/or situation cannot be reached, and the trees always receive both forms in the soil. Therefore it is impossible to say, based on our experiment, if NO3- in the soil is always required for NO emission and whether the emission in the control treatment was induced or not.

Based on our results, it seems unlikely that additional nitrate in the soil could cause significant NOx emission from boreal Scots pine forests in field conditions, possibly because of complex soil chemistry that affects the real nutrient conditions the tree roots experience.

NR induction and consequent nitrite accumulation in the needles would require the NR system in the roots to be saturated (Sarjala 1991). It is likely that the nitrate 
fertilization in our experiment did not achieve this, even though the level was high.

Wildt et al. (1997) observed a transient peak in NO emission during the night after adding nitrate in nutrient solution. Pietiläinen and Lähdesmäki (1988) observed a significant increase in needle NR activity as a function of NO3- concentration in the nutrient solution; the activity increased for $48 \mathrm{~h}$. Adding NH4+ (as (NH4)2SO4) to the solution reduced KNO3-induced NR activity in the needles for $48 \mathrm{~h}$. Thoene et al. (1991) observed a similar transient increase in needle NR activity after fumigation with $\mathrm{NO} 2$, with a maximum after 2 days. In Wildt et al. (1997), the presence of $\mathrm{NH} 4+$ in the nutrient solution prevented any NO emission from the plants. The NO emission seems to be a very short-lived phenomenon related to drastic, abrupt changes in the NO3- concentration of the growth medium. Our experiment, using natural soil, did not produce such dramatic changes. It is unlikely that any changes happening in nature would do so either. The effects of a long-term fertilization (simulating more realistically atmospheric $\mathrm{N}$ deposition in natural conditions) could be clarified with a new experiment, preferably with an improved measurement system. Since the NR activity of pines peaks in the autumn (Lähdesmäki and Pietiläinen 1989), it would be interesting to monitor the possible annual pattern of NOx fluxes with different fertilization treatments.

Acknowledgments This work was supported by the Maj and Tor Nessling Foundation, the Ella and Georg Ehnrooth Foundation and by the Academy of Finland Center of Excellence program (project numbers 1118615 and 272041). The authors thank Kaisa Rissanen for her assistance during the measurements and the Finnish Forest Research Institute (Metla) Haapastensyrjä Unit for the plant material. We also thank Petri Keronen and Ditte Mogensen for valuable comments on the manuscript.

Open Access This article is distributed under the terms of the Creative Commons Attribution License which permits any use, distribution, and reproduction in any medium, provided the original author(s) and the source are credited.

\section{References}

Altimir N, Vesala T, Keronen P, Kulmala M, Hari P (2002) Methodology for direct field measurements of ozone flux to foliage with shoot chambers. Atmos Environ 36:19-29

Andrews M (1986) The partitioning of nitrate assimilation between root and shoot of higher plants. Plant Cell Environ 9: $511-519$
Andrews M, Lea PJ, Raven JA, Lindsey K (2004) Can genetic manipulation of plant nitrogen assimilation enzymes result in increased crop yield and greater N-use efficiency? An assessment. Ann Appl Biol 145:25-40

Andrews M, Raven JA, Lea PJ (2013) Do plants need nitrate? The mechanisms by which nitrogen form affects plants. Ann Appl Biol 163:174-199

Baudoin E (2011) The language of nitric oxide signalling. Plant Biol 13:233-242

Breuninger C, Meixner FX, Kesselmeier J (2013) Field investigations of nitrogen dioxide (NO2) exchange between plants and the atmosphere. Atmos Chem Phys 13:773-790

Chen J, Wua F-H, Liu T-W, Chen L, Xiao Q, Dong X-J, He J-X, Pe Z-M, Zheng H-L (2012) Emissions of nitric oxide from 79 plant species in response to simulated nitrogen deposition. Environ Pollut 160:192-200

De Boer W, Klein Gunnewiek PJA, Troelstra SR (1990) Nitrification in Dutch heathland soils. II. Characteristics of nitrate production. Plant Soil 127:193-200

Eller ASD, Sparks JP (2006) Predicting leaf-level fluxes of O3 and $\mathrm{NO} 2$ : the relative roles of diffusion and biochemical processes. Plant Cell Environ 29:1742-1750

Federer CA, Klemedtsson L (1988) Some factors limiting denitrification in slurries of acid forest soils. Scand J For Res 3:425-435

Frey SD, Knorr M, Parrent JL, Simpson RT (2004) Chronic nitrogen enrichment affects the structure and function of the soil microbial community in temperate hardwood and pine forests. For Ecol Manag 196:159-171

Fröhlich A, Durner J (2011) The hunt for a plant nitric oxide synthase (NOS): Is one really needed? Plant Sci 181:401-404

Gupta KJ, Fernie AR, Kaiser WM, van Dongen JT (2011) On the origins of nitric oxide. Trends Plant Sci 16:160-168

Gut A, Scheibe M, Rottenberger S, Rummel U, Welling M, Ammann C, Kirkman GA, Kuhn U, Meixner FX, Kesselmeier J, Lehmann BE, Schmidt W, Müller E, Piedade MTF (2002) Exchange fluxes of NO2 and O3 at soil and leaf surfaces in an Amazonian rain forest. J Geophys Res 107(D20)

Hari P, Kulmala M (2005) Station for Measuring EcosystemAtmosphere Relations (SMEAR II). Boreal Environ Res 10:315-322

Henrich M, Haselwandter K (1991) Denitrifying potential and enzyme activity in a Norway spruce forest. For Ecol Manag 44:63-68

Henrich M, Haselwandter K (1997) Denitrification and gaseous nitrogen losses from an acid spruce forest soil. Soil Biol Biochem 29:1529-1537

Hereid DP, Monson RK (2001) Nitrogen oxide fluxes between corn (Zea mays L.) and the atmosphere. Atmos Environ 35: 975-983

Hood-Nowotny R, Hinko-Najera Umana N, Inselbacher E, Oswald-Lachouani P, Wanek W (2008) Alternative methods for measuring inorganic, organic, and total dissolved nitrogen in soil. SSSAJ 74:1018-1027

Johansson C (1987) Pine forest: a negligible sink for atmospheric NOx in rural Sweden. Tellus 39B:426-438

Kandeler E, Gerber H (1988) Short-term assay of soil urease activity using colorimetric determination of ammonium. Biol Fertil Soils 6:68-72

Klepper L (1979) Nitric oxide (NO) and nitrogen dioxide $\left(\mathrm{NO}_{2}\right)$ emissions from herbicide-treated soybean plants. Atmos Environ 13:537-542 
Kielland K, McFarland JW, Ruess RW, Olson K (2007) Rapid cycling of organic nitrogen in taiga forest ecosystems. Ecosystems 10:360-368

Korhonen JFJ, Pihlatie M, Pumpanen J, Aaltonen H, Hari P, Levula J, Kieloaho A-J, Nikinmaa E, Vesala T, Ilvesniemi H (2013) Nitrogen balance of a boreal Scots pine forest. Biogeosciences 10:1083-1095

Kulmala M, Rannik Ü, Pirjola L, Dal Maso M, Karimäki J, Asmi A, Jäppinen A, Karhu V, Korhonen H, Malvikko S-P, Puustinen A, Raittila J, Romakkaniemi S, Suni T, Yli-Koivisto S, Paatero J, Hari P, Vesala T (2000) Characterization of atmospheric trace gas and aerosol concentrations at forest sites in southern and northern Finland using back trajectories. Boreal Environ Res 5:315-336

Lähdesmäki P, Pietiläinen P (1989) Seasonal variation in nitrate reductase activity and concentration of NO3-, NO2- and $\mathrm{NH} 4+$ in buds and needles of Scots pine. Aquilo Ser Bot 26:7-11

Lambers H, Chapin FS III, Pons TL (2008) Plant physiological ecology. Springer, New York, p 605

Lindroos AJ, Derome J, Derome K, Niska K (2002) Deposition on the forests and forest floor in 2000. In: Rautjärvi et al. (eds) Finnish Forest Research Institute, Research Papers 879:63-69

Martikainen PJ, Lehtonen M, Lång K, De Boer W, Ferm A (1993) Nitrification and nitrous oxide production potentials in aerobic soil samples from the soil profile of a Finnish coniferous forest site receiving high ammonium deposition. FEMS Microbiol Ecol 13:113-121

Morot-Gaudry-Talarmain Y, Rockel P, Moureaux T, Quilleré I, Leydecker MT, Kaiser WM, Morot-Gaudry JF (2002) Nitrite accumulation and nitric oxide emission in relation to cellular signaling in nitrite reductase antisense tobacco. Planta 215: 708-715

Paavolainen L, Smolander A (1998) Nitrification and denitrification in soil from a clear-cut Norway spruce (Picea abies) stand. Soil Biol Biochem 30:775-781

Persson T, Wirén A (1995) Nitrogen mineralization and potential nitrification at different depths in acid forest soils. Plant Soil 168-169:55-65

Pietiläinen P, Lähdesmäki P (1988) Effect of various concentrations of potassium nitrate and ammonium sulphate on nitrate reductase activity in the roots and needles of Scots pine seedlings in N Finland. Ann Bot Fenn 25:201-206

Pietiläinen P, Poikolainen J, Lähdesmäki P (1991) Long-term monitoring of nitrate reductase activity in the needles of Pinus sylvestris in the context of environmental temperature and ground frost as an indicator of nitrogen balance in N. Finl Ann Bot Fenn 28:131-134

Pirinen P, Simola H, Aalto J, Kaukoranta J-P, Karlsson P, Ruuhela R (2012) Tilastoja Suomen ilmastosta 1981-2010 (Climatological statistics of Finland 1981-2010). Finnish Meteorological Institute Reports 2012:1. 96 p

Raivonen M, Bonn B, Sanz MJ, Vesala T, Kulmala M, Hari P (2006) UV-induced NOy emissions from Scots pine: Could they originate from photolysis of deposited HNO3? Atmos Environ 40:6201-6213
Raivonen M, Joensuu J, Keronen P, Altimir N, Kolari P (2014) Continuous $\mathrm{NO}_{\mathrm{x}}$ flux measurements in the field: observations after changing to photolytic NO2 conversion. Boreal Environ Res 19(suppl B):20-34

Raivonen M, Keronen P, Vesala T, Kulmala M, Hari P (2003) Measuring shoot-level NOx flux in field conditions: the role of blank chambers. Boreal Environ Res 8:445-455

Raivonen M, Vesala T, Pirjola L, Altimir N, Keronen P, Kulmala M, Hari P (2009) Compensation point of NOx exchange: Net result of NOx consumption and production. Agric For Meteorol 149:1073-1081

Ramge P, Badeck FW, Plöchl M, Kohlmaier GH (1993) Apoplastic antioxidants as decisive elimination factors within the uptake process of nitrogen dioxide into leaf tissues. New Phytol 125:771-785

Rockel P, Strube F, Rockel A, Wildt J, Kaiser WM (2002) Regulation of nitric oxide (NO) production by plant nitrate reductase in vivo and in vitro. J Exp Bot 53: 103-110

Rondón A, Granat L (1994) Studies on the dry deposition of NO2 to coniferous species at low $\mathrm{NO} 2$ concentrations. Tellus 46B: 339-352

Rondón A, Johansson C, Granat L (1993) Dry deposition of nitrogen dioxide and ozone to coniferous forests. J Geophys Res 98:5159-5172

Sarjala T (1991) Effect of mycorrhiza and nitrate nutrition on nitrate reductase activity in Scots pine seedlings. Physiol Plant 81:89-94

Schneider CA, Rasband WS, Eliceiri KW (2012) NIH Image to ImageJ: 25 years of image analysis. Nat Methods 9: 671-675

Tang MH, Porder S, Lovett GM (2012) Species differences in nitrate reductase activity are unaffected by nitrogen enrichment in northeastern US forests. For Ecol Manag 275:52-59

Teklemariam TA, Sparks JP (2006) Leaf fluxes of NO and NO2 in four herbaceous plant species: the role of ascorbic acid. Atmos Environ 40:2235-2244

Thoene B, Rennenberg H, Weber P (1996) Absorption of atmospheric NO2 by spruce (Picea abies) trees. II. Parameterization of NO2 fluxes by controlled dynamic chamber experiments. New Phytol 134:257-266

Thoene B, Schröder P, Papen H, Egger A, Rennenberg H (1991) Absorption of atmospheric NO2 by spruce (Picea abies L. Karst.) trees I. NO2 influx and its correlation with nitrate reduction. New Phytol 117:575-585

Wallenstein MD, McNulty S, Fernandez IJ, Boggs J, Schlesinger WH (2006) Nitrogen fertilization decreases forest soil fungal and bacterial biomass in three long-term experiments. For Ecol Manag 222:459-468

Wildt J, Kley D, Rockel A, Rockel P, Segschneider HJ (1997) Emission of NO from several higher plant species. J Geophys Res 102:5919-5927

Willison TW, Anderson JM (1991) Denitrification potentials, controls and spatial patterns in a Norway spruce plantation. For Ecol Manag 44:69-76 